\title{
Behaviour and experiences of dogs during the first year of life predict the outcome in a later temperament test
}

\author{
Pernilla Foyer, Nathalie Bjällerhag, Erik Wilsson and Per Jensen
}

Linköping University Post Print

Tweet

N.B.: When citing this work, cite the original article.

Original Publication:

Pernilla Foyer, Nathalie Bjällerhag, Erik Wilsson and Per Jensen, Behaviour and experiences of dogs during the first year of life predict the outcome in a later temperament test, 2014, Applied Animal Behaviour Science, (155), , 93-100.

http://dx.doi.org/10.1016/j.applanim.2014.03.006

Copyright: Elsevier

http://www.elsevier.com/

Postprint available at: Linköping University Electronic Press

http://urn.kb.se/resolve?urn=urn:nbn:se:liu:diva-109135 


\title{
Behaviour and experiences of dogs during the first year of life predict the outcome in a later temperament test
}

\author{
Pernilla Foyer ${ }^{1,2}$, Nathalie Bjällerhag ${ }^{1}$, Erik Wilsson ${ }^{3}$, Per Jensen ${ }^{1 *}$
}

${ }^{1}$ IFM Biology, AVIAN Behaviour Genomics and Physiology group, Linköping University 58183 Linköping, Sweden

${ }^{2}$ Department of Military Studies, Military-Technology Division, Swedish National Defence College, 11593 Stockholm, Sweden

${ }^{3}$ Swedish Armed Forces Dog Instruction Centre, 19524 Märsta, Sweden

\footnotetext{
${ }^{*}$ Corresponding author at: IFM Biology, AVIAN Behaviour Genomics and Physiology group, Linköping University, 58183 Linköping, Sweden. Phone +46 13 281298, Fax No. +4613 281399. E-mail address: perje@ifm.liu.se (Per Jensen)
} 


\section{Abstract}

Early life experiences are known to shape the behavioural development of animals, and therefore events occurring during preadolescence and adolescence may have long-term effects. In dogs, this period of time may be important for later behaviour and thereby also the suitability of dogs for different working tasks. We used the breeding practice for Swedish military working dogs to investigate this possibility. German Shepherds were bred at a central facility and then kept in host families for about a year, before participating in a standardised test determining their temperament, behaviour, and suitability for further training. We surveyed the link between the behaviour of 71 prospective military working dogs in their home situations during the first year of life as assessed by an amended C-BARQ survey, and their performance in a temperament test (T-test) applied at about 17 months of age. Dogs which scored high for C-BARQ category "Trainability" showed a significantly higher success rate in the T-test $(\mathrm{P}<0.001)$, while dogs that scored high for "Stranger-Directed Fear", "Non-social Fear" and "Dog-Directed Fear" showed a significantly lower success rate (all $\mathrm{P}<0.05$ ). Also dogs with higher $\mathrm{C}$ BARQ scores on "Hyperactivity/Restlessness, Difficulties in Settling Down" (P=0.028), and "Chasing/Following Shadows or Light Spots" ( $\mathrm{P}=0.035)$ were more successful, as were dogs left longer times at home (2.97 \pm 0.32 vs. $2.04 \pm 0.33 \mathrm{~h} /$ day; $\mathrm{P}=0.050)$. Index value, describing the expected success rate in the T-test, was negatively correlated with "Non-social fear" ( $\mathrm{r}=-0.35)$ and "Stranger directed fear" ( $\mathrm{r}=-0.35)$. The combined effect of the significant C-BARQ categories explained $29.5 \%$ of the variance in the later T-test results $(\mathrm{P}=0.006)$. The results indicate that the experiences and behaviour of the dogs during their first year of life is crucial in determining their later behaviour and temperament, something that could potentially be used to improve selection procedures for working dogs. Furthermore, an unsuspected result was that success in the T-test was correlated with behaviours usually associated with problem behaviour, which calls for a deeper analysis of the selection criteria used for working dogs.

Keywords: Working dog, Early experiences, Temperament test, Behaviour, C-BARQ 


\section{Introduction}

The development of the nervous system in altricial species, like the dog, is highly plastic and depends to a large extent on environmental factors (Chapillon et al., 2002; Gazzano et al., 2008). The early postnatal period is crucial (Rosenzweig, 1984), and differences in maternal care or rearing condition can have a major impact (Caldji et al., 1998; Champagne et al., 2003; Macrí and Würbel, 2007; Foyer et al., 2013). However, also later experiences can influence both physiology and behaviour in the adult animal (Dwyer and Lawrence, 2005), making adolescence another important period in behavioural development (Delville et al., 2003; Sachser et al., 2013).

There is a large interest in accurate determination of behaviour and temperament in dogs, partly because this can help improving their daily lives as pets, and partly because there is a need to develop better methods for selecting dogs for different work tasks in human service. Several methods are currently in use for this, and among the most commonly used are standardised behaviour tests, in which subjective or objective ratings of responses to a range of test situations are recorded (Svartberg and Forkman, 2002; Wilsson and Sinn, 2012). Another common method is to use questionnaires, where owners answer a battery of questions relating to the behaviour of dogs in every day life situations (Serpell and Hsu, 2001), or rate behaviour using more subjective language based methods (Ley et al., 2008). At present, the most widely used survey is the Canine Behaviour Assessment and Research Questionnaire (C-BARQ), which was developed based on data from more than 2000 dogs representing more than 100 breeds (Hsu and Serpell, 2003). Duffy and Serpell (2012) found that the C-BARQ is able to identify dogs behaviourally suited for guide or service work as early as at 6 months of age. 
Military tasks, one of the many niches in which dogs may be used for human assistance, calls for optimized methods of evaluation and training (Sinn et al., 2010). For example, the Swedish Armed Forces (SAF) breed and train German Shepherd dogs to become Military Working Dogs (MWDs) within a breeding programme run since 2005. A total of about 200 dogs are bred every year and among them the ones judged to be most suitable are selected for further training. The selection is based on a standardised temperament test (the T-test), from which about $50 \%$ of all tested dogs are rejected due to unsuitable temperament, and about $10 \%$ due to medical issues (calculated from SAF unpublished data). Foyer et al. (2013) found that the results in the T-test are significantly affected by neonatal life experiences of the dogs, and in the present study, we therefore concentrated on behaviour and experiences during the first year of life, including the adolescent period. Pups in the breeding programme leave the kennel after weaning, at an age of 8-10 weeks to live in foster homes, which are volunteer families across the country (hereafter referred to as hosts), and at the age of 15-18 month they undergo the T-test. It is a probable that the behaviour and experiences of the dogs during this biologically important life period may have a significant influence on the success rate in the test.

Batt et al. (2010) found that questionnaires, together with behavioural tests, could predict the probability of success in different guide dog programs and Svartberg (2005) found that results from a behavioural test could to some extent predict behavioural problems in the home environment, related to social and non-social fear. This indicates that there is a strong connection between everyday behaviour in the home environment and the reactions in a standardised temperament test. We therefore decided to use a modified version of the C-BARQ to investigate the behaviour and experiences of the dogs in the family situation during their first year of life. We then 
combined this with the outcome of the T-test and analysed how the assessment of the host families was related to the behaviour during the different sub-tests, and the probability of passing the test and being selected for further training.

The aim of the study was to investigate whether subjective ownerassessment of dog behaviour, and a questionnaire-based account of environmental events during the first year of life, could predict the outcome of a standardised behaviour test applied at about one and a half years of age to prospective MWD. To do so, we made use of both the rating scales used in the T-test: firstly, we examined the actual behaviour scores from all the sub-tests, and secondly, we used the integrated Index Value, which gives an overall value of the perceived suitability of the dog for becoming a working dog. Furthermore, we aimed to improve the understanding of the behavioural characteristics of those dogs, which are selected for further training by means of a brief, standardised selection test, such as the one used by the Swedish Armed Forces. 


\section{Material and Methods}

\subsection{Subjects}

All dogs included in this study were of German Shepherd breed and enrolled within the Swedish Armed Forces (SAF) selective dog-breeding program. More details about the breeding program can be found in Wilsson and Sinn (2012). Briefly, the population consists of purebred German Shepherds stemming from dogs with a variety of genetic background that has been maintained since 2005. About 200 dogs are now bred per year and since the start till 2013, 52\% have been found suitable based on test result in a standardised temperament test (see Section 3 for evaluation methods).

Of the 71 dogs included in this study, 33 were males and 38 females, distributed among 17 different litters ranging from two to 10 in litter size. Bitches arrived at the SAF kennel in Sollefteå in Northern Sweden 3 weeks prior to estimated whelping and were kept there during the whelping and nursing period. At all other times they lived in private foster homes situated across the country. The pups were housed with their mothers and littermates until weaned at an age of 8 weeks, and raised according to the standard routines of the breeding unit (Foyer et al., 2013). After weaning, the pups were placed in foster homes (the so-called hosts) where they remained until the dogs reached the age of 15-18 months. At that time, they were subjected to a standardised temperament test to assess suitability for training. The dogs in this study were born between January and October 2011.

\subsection{The questionnaire}

We used the C-BARQ, translated into Swedish by Svartberg (2005) and supplemented after the final miscellaneous section by the addition of 17 questions relating to 
experiences and major events during the time in the host family. Ninety-five questionnaires were sent out to the puppy hosts, and 71 were completed and returned, corresponding to a response rate of $74.7 \%$.

The modified survey consisted of 122 questions (for the complete set of questions, see Supplementary material 1). The majority of the questions were answered on a 5-point scale (0-4) or a relative frequency scale (never, seldom, sometimes, usually and often), but a few required written answers, which were then categorised before statistical analysis. The C-BARQ provides a set of quantitative scores for 14 different categories of behaviour calculated as a mean from all the item scores or questions within a factor (Table 1).

The dogs were approximately 14month (418 \pm 58.6 days) old when the hosts filled in the questionnaires. They were asked to answer all questions and only omit an answer if the described situation had never been observed. Omitted answers in the miscellaneous section were treated as missing values. The values of each of the 14 categories of the C-BARQ were composite scores from a number of questions, and if omitted answers were found in any of these questions, and this resulted in more than $20 \%$ loss of the questions within that category, the whole category was treated as a missing value for that individual. Otherwise, the mean values of the remaining questions were used for this category. The question about food type was later excluded since all dogs were fed the same food according to the instructions from the breeding unit. The answers concerning whether there were other animals and other dogs in the household were pooled to "living with other animals; yes/no" and the answers concerning engagement in different types of training activities with their dog were pooled into "had been trained or not". Information about re-homing (if the dog had moved from one host to another) was obtained from the SAFs database. 


\subsection{Temperament test}

The purpose of the temperament test (T-test) was to evaluate the suitability of the dogs for training to become future military working dogs. For a detailed description of the Ttest and its different parts, see Wilsson and Sinn (2012). Briefly, the T-test assesses the behaviour of the dog in 12 different sub-test situations, using two different rating protocols. One is the Behavioural Rating protocol (BR), where 25 behavioural variables in total are measured (see Supplementary material 2 for definitions and scoring of the behavioural variables), and the second is Subjective Rating protocol (SR), where 13 different traits are rated. The 12 sub-tests measure the reactions of the dogs to a range of different potentially fearful stimuli, such as suddenly appearing dummies, loud noise or frightening floor structures, and the willingness of the dog to cooperate and engage in social interactions with humans.

We obtained the complete T-test results from the 71 dogs for which we had a complete survey response, and the whole test took about $40 \mathrm{~min}$ to complete per dog. The same person, who had extensive experience with this test, assessed the behaviour of all dogs. The test leader was blind to the C-BARQ results. Males were tested before females to eliminate the risk of distraction from pre-oestrous females on males. The dogs were between approximately 17 month old (504.0 \pm 28.9 days) when tested.

\section{Statistical analysis}

The behavioural scores, based on the 25 behavioural variables in the BR from the 12 sub-tests in the T-test (Temperament test), were entered into a principal component analysis (PCA). The primary factor solution was orthogonally rotated using the Varimax normalized rotation method, due to the relatively small sample size. The sampling 
adequacy was tested using the Bartlett's sphericity test and the Kaiser-Meyer-Olkin (KMO) measure (Budaev, 2010) and the correlation matrix of the standardised T-test was deemed appropriate for PCA (Bartlett's sphericity $\chi^{2}(253)=828.7, \mathrm{P}<0.001$; $\mathrm{KMO}=0.733)$.

Based on the SR-scores from the 12 sub-tests, each dog was also assigned an Index Value. For the exact methods used for calculating the Index Value, see Wilsson and Sundgren (1997). Briefly, it was calculated by comparing the SR-test results of a particular dog with earlier, historical results of all previously tested dogs and their later success or failure in the actual training phase. An Index Value of zero signifies a $50 \%$ chance of being successful in training, and the higher the total Index Value, the greater the chance that the dog will become a successful working dog. In the presently tested dogs, the Index Value ranged from -60 to +93 . Dogs with Index Values below 0 were considered to have failed the test, and were not retained for training. The Index Value provides an unbiased integrated measure of suitable temperament from the perspective of the armed forces, and we therefore used this for our comparisons with the survey data in addition to the actual behavioural data from the T-test.

To investigate whether there were any relationships between the behaviour in the T-test and the C-BARQ categories, C-BARQ items and survey items, Pearson correlation coefficients between PCA factor scores, Index Value and C-BARQ were calculated. The level of significance was set to $\mathrm{P}<0.05$ for all analysis. All data was analysed using SPSS 21.0.

We used an Independent samples t-test to check the significance of any effects of sex or re-homing, and Pearson Correlation to check for effects of litter size or age at testing on the T-test results. Regression analysis was used to determine the amount of variance in T-test results explained by C-BARQ responses. 
In order to estimate the amount of variance of the T-test data that was explained by the C-BARQ responses, we carried out a regression analysis. The Index Value was used as the independent variable, and the five different C-BARQ categories found to be significantly related to the Index Value were used as independent main effects.

\section{Results}

No significant correlations between Index Value and number of pups per litter $(\mathrm{r}=-$ 0.109, $\mathrm{P}=0.365)$, or age at testing $(\mathrm{r}=-0.031, \mathrm{P}=0.802)$ were found. Furthermore, there were no effects of $\operatorname{sex}(t=0.193, P=0.847)$ or re-homing $(t=1.059, P=0.293)$ on Index Value. Therefore, data from all dogs were pooled for subsequent analyses.

Dogs with Index Value $>0$ had a significantly higher score for the C-BARQ category "Trainability" $\left(\mathrm{t}_{(69)}=3.82, \mathrm{P}<0.001\right)$ and C-BARQ items “Hyperactivity/Restlessness, Difficulties in Settling Down" $\left(\mathrm{t}_{(69)}=2.25, \mathrm{P}=0.028\right)$, and “Chasing/Following Shadows or Light Spots" $\left(\mathrm{t}_{(68)}=2.16, \mathrm{P}=0.035\right)$ (Fig. 1). Furthermore, dogs with Index Value $>0$ were left significantly longer alone at home per day $(2.97 \pm 0.32$ vs. $2.04 \pm 0.33 \mathrm{~h} /$ day; $\mathrm{t}_{(66)}=2.00, \mathrm{P}=0.050$ ). Dogs with an Index Value $<0$, on the other hand, had a significantly higher score for the C-BARQ categories "Stranger-Directed Fear" $\left(\mathrm{t}_{(34)}=-2.48, \mathrm{P}=0.018\right)$, “Non-Social Fear" $\left(\mathrm{t}_{(43)}=-3.01, \mathrm{P}=0.004\right)$, "Dog-Directed Fear" $\left(\mathrm{t}_{(29)}=-2.38, \mathrm{P}=0.024\right)$ and "Touch Sensitivity" $\left(\mathrm{t}_{(42)}=-2.23, \mathrm{P}=0.031\right)$ (Fig. 1).

The categories included in the regression analysis, to determine amount of variance in T-test results explained by C-BARQ scores, were those shown in Fig 1, i e, "Stranger Directed Fear", “Non-Social Fear”, “Dog-Directed Fear”, “Touch Sensibility”, and "Trainability". The model was statistically significant $\left(\mathrm{F}_{5.45}=3.8 ; \mathrm{P}=0.006\right)$. Although 
only "Trainability" was significant as main factor $\left(\mathrm{F}_{1.45}=5.6 ; \mathrm{P}=0.023\right)$, the explained variance $\left(\mathrm{R}^{2}\right)$ of the model was $29.5 \%$.

The principal component analysis on the T-test variables revealed six components with eigenvalues greater than 1 , which together explained $70.9 \%$ of the total variance $(\mathrm{N}=71)$. The criterion for considering a T-test variable relevant to a specific principal component (PC) was set to a loading of 0.5 or above (Table 2). The first PC had high loadings of variables related to behavioural responses to startling stimuli and was named "Confidence" in accordance with previous research. The second PC described willingness to engage with inanimate objects and was labelled "Physical Engagement". In the same way, the third PC described variation with respect to level of engagement with humans and was hence named "Social Engagement". The fourth PC described variations in "Environmental Sureness" and was defined by reactions to an unknown environmental condition, while the fifth PC was spanned by ratings concerning the acoustic startle sub-test and was therefore named "Acoustic Environmental Sureness". Finally, the sixth PC described variations in aggressive responses to the visual and gradual visual startle sub-tests and was hence named “Aggression”.

There were significant correlations between the Index Value and all PC scores except for "Acoustic Environmental Sureness" (Table 3). Furthermore, for each of the PC scores "Confidence”, "Physical Engagement" and "Aggression”, there were significant correlations with at least one of the 14 C-BARQ categories (Table 3). The PC "Confidence" correlated negatively with C-BARQ category "Non-Social Fear" and "Excitability", while PC "Physical Engagement" correlated positively with C-BARQ category "Trainability" and negatively with both the C-BARQ categories "Non-Social Fear" and "Touch Sensitivity". PC "Aggression" showed a positive correlation with C- 
BARQ category "Stranger-Directed Aggression" and a negative correlation to C-BARQ category "Dog-Directed Fear".

Among the added, miscellaneous questions, there was a significant positive correlation between the PC "Environmental Sureness" and the survey item "Hours left home alone per day" $(\mathrm{r}=0.271, \mathrm{P}=0.034, \mathrm{~N}=61)$, and a significant negative correlation between score on PC "Social Engagement" and the survey item "Hours on average of activation per day" ( $\mathrm{r}=-0.308, \mathrm{P}=0.015, \mathrm{~N}=62$ ) (Table3). There was no correlation between "Hours left home alone per day" and the score on having other animals in the household.

\section{Discussion}

The results of the present study show that dogs passing the T-test (i.e., with an Index Value $>0$ ) scored high on the C-BARQ category "Trainability" and C-BARQ items "Hyperactive/Restlessness, Difficulties in Settling Down", and "Chasing/Following Shadows or Light Spots". They were also on average left home alone more hours per day. Furthermore, the behavioural outcome of the T-test was significantly related to scores on several C-BARQ categories. These results show that important aspects of dog behaviour, which were of central importance for the ability to pass the T-test, could already be assessed during the first year of life in the home environments. This further opens novel possibilities to improve the selection procedure for military working dogs by involving the host families in the assessment, or by including a broader assessment of dog behaviour during the first year of life. Even though dog owner reports in general have a greater risk for subjective bias compared to more objective behavioural observation methods, the various C-BARQ items are designed to reduce such biases by 
focusing on the dog's response to a specific situation or stimuli (Hsu and Serpell, 2003; Duffy et al., 2008).

With respect to the Index Value results, the C-BARQ category "Trainability" had a significant predictive value for the probability of successfully passing the T-test, which appears quite logical. However, it is perhaps more surprising that dogs scoring higher on C-BARQ items "Hyperactive/Restlessness, Difficulties in Settling Down", and "Chasing/Following Shadows or Light Spots" were more successful. These traits are typically associated with behavioural problems (Wells and Hepper, 2000) and a lesser chance to succeed as a guide dog (Tomkins et al., 2011). However, this association between success in the T-test and C-BARQ items "Hyperactive/Restlessness, Difficulties in Settling Down", and "Chasing/Following Shadows or Light Spots", and which might signify that dogs passing the T-test tend to be somewhat hyperactive and obsessive/compulsive, do not necessarily means that these traits are negative in a MWD even though they probably would be in a pet or guide dog. Further, it may also be interpreted as a higher stress level in these dogs, and would not be expected to be associated with the ability to handle the stressful situation of the T-test. It appears that the T-test favours dogs which have a highly active personality type, and further research should focus on whether this is actually a preferred trait for a MWD.

Dogs with an Index Value>0 (hence being selected for training) were on average left alone at home longer per day than unsuccessful dogs. Again, this is a somewhat counterintuitive result, since time left alone at home is generally related to higher incidences of a variety of behavioural problems in dogs (Kobelt et al., 2003; Taylor and Mills, 2007). However, since this is a strict correlational result, it is quite possible that the most stress-resistant dogs are more often left alone longer, simply 
because they can handle this without obvious negative consequences from the perspective of the hosts.

Dogs with Index Value $<0$ scored high on C-BARQ categories "StrangerDirected Fear”, “Non-Social Fear”, “Dog-Directed Fear” and "Touch Sensitivity” which is in line with what might be expected, since an MWD is desired not to be fearful. The significant relationships between these traits from the C-BARQ and the risk of failure in the temperament test show that the probability to pass the test can successfully be predicted by the survey. This is in line with earlier studies on other categories of dogs showing that the C-BARQ is able to discriminate between dogs that are well suited for guide and assistance work and those which are not (Duffy and Serpell, 2012). Although the number of dogs was relatively limited, using the combination of five different CBARQ categories as predictors explained almost $30 \%$ of the variation in Index Value. This indicates that background information about the experiences and perceived traits of a dog during its first year of life could significantly improve the selection of suitable MWDs.

Focusing on the behavioural outcomes in the different sub-tests, the PCA showed results highly consistent with previous research of dog temperament, which have used a range of methods (Svartberg and Forkman, 2002; Ley et al., 2008; Mirkó et al., 2012; Wilsson and Sinn, 2012; Foyer et al., 2013). The factor scores obtained in the present analysis were based on a relatively limited number of dogs. The T-test has earlier been subjected to much more comprehensive analysis, aimed at determining personality dimensions in putative military dogs. However, in the present analysis, the purpose of the statistical testing was only to reduce the number of behavioural variables, not to impose the results on any particular personality model. Since we specifically wanted to compare the C-BARQ results with the T-test results of the same 
dogs, we therefore decided to base this comparison on a Principal Components Analysis of these dogs only, rather than, for example, superimposing the T-test outcome on previous independent factor analysis results. Nevertheless, there is considerable agreement between this and previous analyses of the same behaviour test as the one used here (Wilsson and Sinn, 2012), where the PCA generated five PCs with eigenvalues $>$ 1, named "Confidence”, "Physical Engagement", "Social Engagement”, “Aggression” and "Environmental Sureness". In general, that study was highly consistent with this one (see Supplementary material 3 for a comparison regarding Component scores between these two studies). Although the current study produced six PCs with eigenvalues $>1$, the difference between the studies is most likely due to the large difference in numbers of dogs included. PC1 i.e. "Confidence" in both studies both comprises strong loadings of the behavioural variables Visual Flight distance, Visual Secondary response, Visual Lasting effect, Gradually Visual Fearfulness, Gradually Visual Secondary response, and Gradually Visual Lasting effect. However, in Wilsson and Sinn (2012) also the behavioural variables Acoustic Flight distance and Acoustic Lasting effect loaded strong for "Confidence". The second PC, "Physical Engagement" hold strong loadings for behavioural variables Tug-of-war, Chasing, Interest in object, Object, Search Intensity and Search Persistence in both studies, but also the behavioural variable Leash loaded strong in Wilsson and Sinn (2012). Regarding the behavioural variables for "Social Engagement" i.e. Affability, Handling and Leash, the agreement was complete between the two studies, as with PC "Aggression" which in both studies comprised behavioural variables Visual Aggression, Gradually Visual Fearfulness and Gradually Visual Aggression. PCs "Environmental Sureness" and "Acoustic Environmental Sureness" in this study both correspond to Wilsson and Sinn's (2012) PC “Environmental Sureness", with perfect but sign reversed coherence between the behavioural variables Reaction in 
dark room, Metal stair, Reaction on table, Acoustic Flight distance, Acoustic Secondary response and Acoustic Lasting effect. Signs may be reversed on some PC:s when comparing different PCA:s of similar material, due to the fact that different numbers of PC:s are extracted. However, as long as variables show similar aggregations within the same PC, they can be considered similar factor solutions. Hence, in spite of the small differences in factor structure, the present results add further support to the notion that the reaction of dogs in complex behaviour tests is largely determined by a relatively small number of personality traits that are highly consistent between different experiments.

Scores on three of the six PCs - "Confidence", "Physical Engagement" and "Aggression" - were associated with behaviour in the home environment, as assessed by the hosts in the C-BARQ questionnaire. This indicates that fundamental aspects of dog personality could successfully be assessed by the owners relatively early in the life of the dogs, and this in turn was highly related to the behavioural outcome of the standardised T-test. This opens up an important possibility to improve the selection of dogs by incorporating assessments by hosts that integrate observations over the entire first year of life. The present results do not allow us to determine how much the selection process could be improved by this, but this could be an important aspect of future research.

The results also call for more research on determining which traits are actually desired during the selection process of MWD, since it appears that the suitability test favours dogs which show behaviours which are often interpreted as signs of higher stress levels in their home environments, and also dogs which are left longer alone at home. Further studies should concentrate on improving the understanding of 
how the T-test is perceived by the dogs, for example the extent to which it provokes fear and stress reactions, and how this relates to the traits desired in a functional MWD.

\section{Conclusions}

Our results show that important aspects of dog behaviour assessed in everyday life situations by the host families during the first year of life could to some extent predict the outcome of the T-test and be used as a complimentary tool when evaluating prospective MWDs. The use of C-BARQ can therefore probably be used to improve the selection procedure of MWDs.

\section{Acknowledgements}

We would like to thank James Serpell for allowing us to use the C-BARQ in this study and Kenth Svartberg for his sharing of the translated version of the C-BARQ. Further would we like to thank the Swedish Armed Forces Dog Instruction Centre for permitting us to use the data record and test results of their dogs, and Mikael Pouno for help with the records of hosts. We would also like to thank the hosts for participating. The study was performed within the framework of the Swedish National Defence College doctoral program and the Swedish Centre of Excellence in Animal Welfare Science, financed by the research council FORMAS. Financial support was also received from the European Research Council, within the advanced grant project GENEWELL (ERC 322206). 


\section{References}

Batt, L., Batt, M., Baguley, J., McGreevy, P., 2010. Relationships between puppy management practices and reported measures of success in guide dog training. J Vet Behav 5, 240-246.

Budaev, S.V., 2010. Using Principal Components and Factor Analysis in Animal Behaviour Research: Caveats and Guidelines. Ethology 116, 472-480.

Caldji, C., Tannenbaum, B., Sharma, S., Francis, D., Plotsky, P.M., Meaney, M.J., 1998. Maternal care during infancy regulates the development of neural systems mediating the expression of fearfulness in the rat. Proc. Natl. Acad. Sci. 95, 53355340 .

Champagne, F.A., Francis, D.D., Mar, A., Meaney, M.J., 2003. Variations in maternal care in the rat as a mediating influence for the effects of environment on development. Physiology and Behavior 79, 359-371.

Chapillon, P., Patin, V., Roy, V., Vincent, A., Caston, J., 2002. Effects of pre- and postnatal stimulation on developmental, emotional, and cognitive aspects in rodents: A review. Developmental Psychobiology 41, 373-387.

Delville, Y., David, J.T., Taravosh-Lahn, K., Wommack, J.C., 2003. Stress and the development of agonistic behavior in golden hamsters. Hormones and behavior 44, 263-270.

Duffy, D.L., Hsu, Y.Y., Serpell, J.A., 2008. Breed differences in canine aggression. Appl Anim Behav Sci 114, 441-460.

Duffy, D.L., Serpell, J.A., 2012. Predictive validity of a method for evaluating temperament in young guide and service dogs. Appl Anim Behav Sci 138, 99-109.

Dwyer, C.M., Lawrence, A.B., 2005. A review of the behavioural and physiological adaptations of hill and lowland breeds of sheep that favour lamb survival. Appl Anim Behav Sci 92, 235-260.

Foyer, P., Wilsson, E., Wright, D., Jensen, P., 2013. Early experiences modulate stress coping in a population of German shepherd dogs. Appl Anim Behav Sci 146, 79-87.

Gazzano, A., Mariti, C., Notari, L., Sighieri, C., McBride, E.A., 2008. Effects of early gentling and early environment on emotional development of puppies. Appl Anim Behav Sci $110,294-304$.

Hsu, Y.Y., Serpell, J.A., 2003. Development and validation of a questionnaire for measuring behavior and temperament traits in pet dogs. J Am Vet Med Assoc 223, 1293-1300.

Kobelt, A.J., Hemsworth, P.H., Barnett, J.L., Coleman, G.J., 2003. A survey of dog ownership in suburban Australia - conditions and behaviour problems. Appl Anim Behav Sci 82, 137-148.

Ley, J., Bennett, P., Coleman, G., 2008. Personality dimensions that emerge in companion canines. Appl Anim Behav Sci 110, 305-317.

Macrí, S., Würbel, H., 2007. Effects of variation in postnatal maternal environment on maternal behaviour and fear and stress responses in rats. Animal Behavior 73, 171181. 
Mirkó, E., Kubinyi, E., Cácsi, M., Miklósi, A., 2012. Preliminary analysis of an adjectivebased dog personality questionnaire developed to measure some aspects of personality in the domestic dog (Canis familaris). Appl Anim Behav Sci 138, 88-98.

Rosenzweig, M.R., 1984. Experience, memory, and the brain. Am Psychol 39, 365-376.

Sachser, N., Kaiser, S., Hennessy, M.B., 2013. Behavioural profiles are shaped by social experience: when, how and why. Philos Trans R Soc Lond B Biol Sci 368, 20120344.

Serpell, J.A., Hsu, Y., 2001. Development and validation of a novel method evaluating behaviour and temperament in guide dogs. Appl Anim Behav Sci 72, 347-364.

Sinn, D.L., Gosling, S.D., Hilliard, S., 2010. Personality and performance in military working dogs: Reliability and predictive validity of behavioral tests. Appl Anim Behav Sci 127, 51-65.

Svartberg, K., 2005. A comparsion of behaviour test and in everyday life: evidence of three consistent boldness-related personality traits in dogs. Appl Anim Behav Sci 91, 103-128.

Svartberg, K., Forkman, B., 2002. Personality traits in the domestic dog (Canis familaris). Appl Anim Behav Sci 79, 133-155.

Taylor, K.D., Mills, D.S., 2007. The effect of the kennel environment on canine welfare: a critical review of experimental studies. Anim Welfare 16, 435-447.

Tomkins, L.M., Thomson, P.C., McGreevy, P.D., 2011. Behavioral and physiological predictors of guide dog success. J Vet Behav 6, 178-187.

Wells, D.L., Hepper, P.G., 2000. Prevalence of behaviour problems reported by owners of dogs purchased from an animal rescue shelter. Appl Anim Behav Sci 69, 55-65.

Wilsson, E., Sinn, D., 2012. Are there differences between behavioral measurement methods? A comparsion of the predictive validity of two rating methods in a working dog program. Appl Anim Behav Sci 141, 158-172.

Wilsson, E., Sundgren, P.-E., 1997. The use of a behaviour test for selection of dogs for service and breeding I: Methods of testing and evaluating test results in the adult dog, demands on different kinds of service dogs, sex and breed differances. Appl Anim Behav Sci 53, 279-295. 


\section{Tables}

Table 1. The 14 different C-BARQ categories, which are represented by a set of quantitative scores, and the number of items or questions in the questionnaire that represents each category. A general summary description of the main behaviour signifying each category is also presented.

\begin{tabular}{|c|c|c|}
\hline $\begin{array}{l}\text { C-BARQ } \\
\text { categories }\end{array}$ & $\begin{array}{l}\text { Number } \\
\text { of items }\end{array}$ & Description of category \\
\hline $\begin{array}{l}\text { Stranger- } \\
\text { Directed } \\
\text { Aggression }\end{array}$ & 10 & $\begin{array}{l}\text { Dog shows threatening or aggressive responses to strangers } \\
\text { approaching or invading the dog's or owner's personal space, } \\
\text { territory, or home range. }\end{array}$ \\
\hline $\begin{array}{l}\text { Owner-Directed } \\
\text { Aggression }\end{array}$ & 8 & $\begin{array}{l}\text { Dog shows threatening or aggressive responses to the owner or } \\
\text { other members of the household when challenged, handled, stared } \\
\text { at, stepped over, or when approached while in possession of food or } \\
\text { objects. }\end{array}$ \\
\hline $\begin{array}{l}\text { Dog-Directed } \\
\text { Aggression }\end{array}$ & 4 & $\begin{array}{l}\text { Dog shows threatening or aggressive responses when approached } \\
\text { directly by unfamiliar dogs. }\end{array}$ \\
\hline $\begin{array}{l}\text { Stranger- } \\
\text { Directed Fear }\end{array}$ & 4 & $\begin{array}{l}\text { Dog shows fearful or wary responses when approached directly by } \\
\text { strangers. }\end{array}$ \\
\hline Non-Social Fear & 6 & $\begin{array}{l}\text { Dog shows fearful or wary responses to sudden or loud noises, } \\
\text { traffic, and unfamiliar objects and situations. }\end{array}$ \\
\hline $\begin{array}{l}\text { Dog-Directed } \\
\text { Fear }\end{array}$ & 4 & $\begin{array}{l}\text { Dog shows fearful or wary responses when approached directly by } \\
\text { unfamiliar dogs. }\end{array}$ \\
\hline $\begin{array}{l}\text { Separation- } \\
\text { Related } \\
\text { Behaviour }\end{array}$ & 9 & $\begin{array}{l}\text { Dog vocalizes and/or is destructive when separated from the owner, } \\
\text { often accompanied or preceded by behavioural and autonomic signs } \\
\text { of anxiety including restlessness, loss of appetite, trembling, and } \\
\text { excessive salivation. }\end{array}$ \\
\hline $\begin{array}{l}\text { Attachment and } \\
\text { Attention- } \\
\text { Seeking }\end{array}$ & 7 & $\begin{array}{l}\text { Dog maintains close proximity to the owner or other members of the } \\
\text { household, solicits affection or attention, and displays agitation when } \\
\text { the owner gives attention to third parties. }\end{array}$ \\
\hline Trainability & 8 & $\begin{array}{l}\text { Dog shows willingness to attend to the owner, obeys simple } \\
\text { commands, learns quickly, fetches objects, responds positively to } \\
\text { correction, and ignores distracting stimuli. }\end{array}$ \\
\hline Chasing & 4 & $\begin{array}{l}\text { Dog chases cats, birds, and/or other small animals, given the } \\
\text { opportunity. }\end{array}$ \\
\hline Excitability & 6 & $\begin{array}{l}\text { Dog displays strong reaction to potentially exciting or arousing } \\
\text { events, such as going for walks or car trips, doorbells, arrival of } \\
\text { visitors, and the owner arriving home; has difficulty settling down } \\
\text { after such events. }\end{array}$ \\
\hline Touch Sensitivity & 4 & $\begin{array}{l}\text { Dog shows fearful or wary responses to potentially painful } \\
\text { procedures, including bathing, grooming, nail-clipping, and veterinary } \\
\text { examinations. }\end{array}$ \\
\hline Energy Level & 2 & Dog is energetic, "always on the go", and/or playful. \\
\hline Dog Rivalry & 4 & $\begin{array}{l}\text { Dog shows aggressive or threatening responses to other familiar } \\
\text { dogs in the household }\end{array}$ \\
\hline
\end{tabular}


Table 2. Results from the principal component analysis, after Varimax rotation with Kaiser Normalization. The table shows the Temperament test variable loadings on the six components with eigenvalues $>1$. Loadings over 0.5 are shown in bold. A= Acoustic Startle sub-test; $G=$ Gradual Visual Startle sub-test; V= Visual Startle sub-test. The total variance explained by the six factors is $70.9 \%$. $N=71$.

\begin{tabular}{lcccccc}
\hline & \multicolumn{5}{c}{ Principal Component } \\
\cline { 2 - 7 } Behavioural variable & Confidence & $\begin{array}{l}\text { Physical } \\
\text { Engagement }\end{array}$ & $\begin{array}{l}\text { Social } \\
\text { Engagement }\end{array}$ & $\begin{array}{l}\text { Environmental } \\
\text { Sureness }\end{array}$ & $\begin{array}{l}\text { Acoustic } \\
\text { Environmental } \\
\text { Sureness }\end{array}$ & $\begin{array}{c}\text { Aggression } \\
\text { V. Flight distance }\end{array}$ \\
\cline { 2 - 7 } V. Secondary response & $\mathbf{0 . 6 5}$ & 0.23 & 0.13 & -0.29 & 0.32 & 0.20 \\
V. Lasting effect & $\mathbf{0 . 8 0}$ & 0.02 & 0.06 & 0.08 & 0.15 & -0.14 \\
G. Fearfulness & $\mathbf{0 . 8 6}$ & 0.05 & 0.05 & -0.02 & 0.11 & 0.00 \\
G. Secondary response & $\mathbf{0 . 6 5}$ & 0.08 & -0.18 & -0.02 & 0.05 & $\mathbf{0 . 5 5}$ \\
G. Lasting effect & $\mathbf{0 . 8 4}$ & 0.01 & -0.04 & 0.16 & 0.11 & 0.19 \\
Tug-of-war & $\mathbf{0 . 7 5}$ & 0.05 & 0.11 & 0.20 & 0.20 & 0.20 \\
Chasing & -0.08 & $\mathbf{0 . 6 9}$ & 0.26 & 0.10 & 0.20 & 0.13 \\
Interest in object & -0.05 & $\mathbf{0 . 8 1}$ & 0.13 & 0.20 & 0.03 & 0.09 \\
Object & 0.04 & $\mathbf{0 . 7 6}$ & -0.02 & 0.18 & 0.05 & 0.21 \\
Search Intensity & -0.07 & $\mathbf{0 . 7 4}$ & 0.15 & 0.29 & 0.06 & -0.12 \\
Search Persistence & 0.24 & $\mathbf{0 . 8 3}$ & -0.01 & 0.03 & 0.08 & -0.12 \\
Affability & 0.33 & $\mathbf{0 . 7 6}$ & 0.00 & 0.04 & 0.03 & -0.11 \\
Handling & 0.03 & 0.29 & $\mathbf{0 . 6 8}$ & 0.00 & -0.08 & -0.02 \\
Leash & -0.01 & -0.17 & $\mathbf{0 . 8 6}$ & -0.03 & 0.02 & -0.13 \\
Reaction in dark room & 0.12 & 0.25 & $\mathbf{0 . 8 1}$ & 0.14 & -0.08 & -0.01 \\
Metal stair & 0.33 & 0.23 & -0.15 & $\mathbf{0 . 7 7}$ & 0.04 & -0.15 \\
Reaction on table & 0.07 & 0.26 & 0.27 & $\mathbf{0 . 7 2}$ & 0.07 & 0.19 \\
A. Flight distance & -0.11 & 0.38 & 0.05 & $\mathbf{0 . 7 3}$ & 0.22 & 0.14 \\
A. Secondary response & 0.19 & 0.19 & -0.08 & -0.10 & $\mathbf{0 . 8 0}$ & 0.11 \\
A. Lasting effect & 0.17 & 0.00 & -0.11 & 0.29 & $\mathbf{0 . 7 0}$ & -0.01 \\
V. Aggression & 0.29 & 0.12 & 0.04 & 0.12 & $\mathbf{0 . 7 1}$ & 0.19 \\
G. Aggression & -0.01 & -0.03 & -0.07 & 0.04 & 0.10 & $\mathbf{0 . 8 0}$ \\
\% variance explained & 0.40 & 0.06 & -0.04 & 0.10 & 0.15 & $\mathbf{0 . 7 1}$ \\
\hline & 17.9 & 17.8 & 9.4 & 9.2 & 8.6 & 8.0 \\
\hline
\end{tabular}


Table 3. Pearson correlation coefficients between the Index Value (IV) and all PC scores, and between PC scores and seven of the 14 CBARQ categories and some survey items in the miscellaneous section. The table includes coefficient and (P-value), * significant at the 0.05 level.

\begin{tabular}{|c|c|c|c|c|c|c|c|}
\hline & Index Value & Confidence & $\begin{array}{l}\text { Physical } \\
\text { Engagement }\end{array}$ & $\begin{array}{l}\text { Social } \\
\text { Engagement }\end{array}$ & $\begin{array}{l}\text { Environmental } \\
\text { Sureness }\end{array}$ & $\begin{array}{l}\text { Acoustic } \\
\text { Environmental } \\
\text { Sureness }\end{array}$ & Aggression \\
\hline Index Value & & $0.531^{*}(<0.001)$ & $0.481^{*}(<0.001)$ & $0.253^{*}(0.044)$ & $0.262^{\star}(0.036)$ & $0.151(0.233)$ & $0.313^{*}(0.012)$ \\
\hline $\begin{array}{l}\text { Stranger-Directed } \\
\text { Aggression }\end{array}$ & $-0.045(0.711)$ & $0.090(0.480)$ & $-0.041(0.748)$ & $-0.128(0.313)$ & $-0.127(0.318)$ & $0.022(0.861)$ & $0.303^{*}(0.015)$ \\
\hline Stranger-Directed Fear & $-0.359 *(0.002)$ & $-0.130(0.309)$ & $0.013(0.921)$ & $-0.185(0.147)$ & $-0.183(0.152)$ & $-0.134(0.296)$ & $-0.059(0.647)$ \\
\hline Non-Social Fear & $-0.350 *(0.003)$ & $-0.351^{*}(0.004)$ & $-0.265^{\star}(0.034)$ & $-0.063(0.619)$ & $-0.137(0.280)$ & $-0.175(0.167)$ & $0.045(0.726)$ \\
\hline Dog-Directed Fear & $-0.352^{*}(0.009)$ & $-0.124(0.401)$ & $-0.043(0.770)$ & $-0.101(0.494)$ & $0.011(0.943)$ & $-0.153(0.300)$ & $-0.320^{*}(0.027)$ \\
\hline Trainability & $0.335^{*}(0.004)$ & $0.057(0.653)$ & $0.376^{*}(0.002)$ & $0.004(0.974)$ & $0.057(0.656)$ & $0.067(0.596)$ & $-0.010(0.939)$ \\
\hline Excitability & $-0.106(0.378)$ & $-0.259^{*}(0.039)$ & $-0.138(0.277)$ & $0.016(0.898)$ & $-0.211(0.095)$ & $0.050(0.697)$ & $0.063(0.618)$ \\
\hline Touch Sensitivity & $-0.187(0.133)$ & $0.043(0.742)$ & $-0.282^{*}(0.029)$ & $-0.080(0.544)$ & $-0.058(0.662)$ & $-0.160(0.223)$ & $0.057(0.666)$ \\
\hline $\begin{array}{l}\text { Chases/follows shadows, } \\
\text { light spots }\end{array}$ & $0.286^{*}(0.016)$ & $0.244(0.054)$ & $0.118(0.358)$ & $-0.127(0.322)$ & $-0.069(0.592)$ & $-0.020(0.876)$ & $0.240(0.058)$ \\
\hline $\begin{array}{l}\text { Hours on average left } \\
\text { home alone per day }\end{array}$ & $0.194(0.112)$ & $0.009(0.942)$ & $-0.015(0.908)$ & $0.075(0.566)$ & $0.271^{*}(0.034)$ & $-0.055(0.674)$ & $0.212(0.100)$ \\
\hline $\begin{array}{l}\text { Hours on average of } \\
\text { activation per day }\end{array}$ & $0.154(0.206)$ & $0.183(0.154)$ & $-0.130(0.316)$ & $-0.308^{*}(0.015)$ & $-0.194(0.132)$ & $-0.116(0.370)$ & $0.143(0.267)$ \\
\hline
\end{tabular}




\section{Figures}

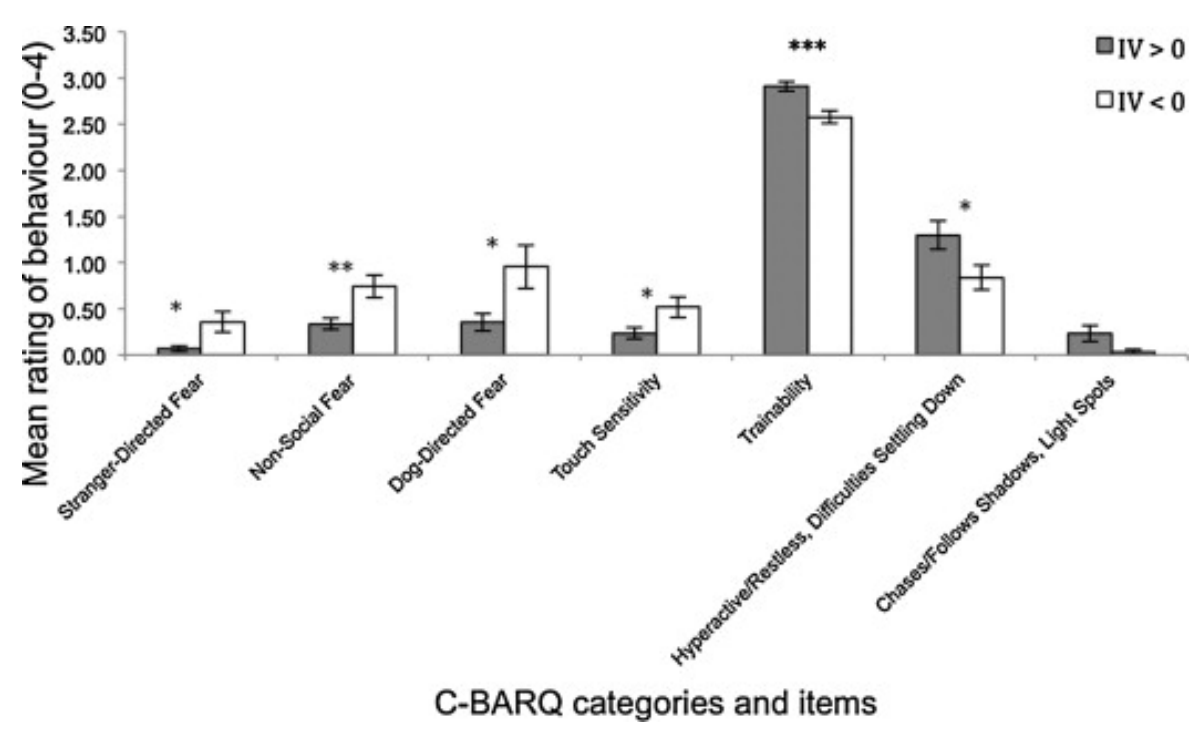

Fig. 1. Mean ratings (with SEM) for C-BARQ categories in dogs with Index Values (IV) greater and less than 0 respectively, where IV $>0$ signifies a higher than average probability of successful training outcome, and IV $<0$ a lower probability. Significant differences are indicated by asterisks (*: $\mathrm{P}<0.05$; ${ }^{* *}: \mathrm{P}<0.01$; $\left.{ }^{* *}: \mathrm{P}<0.001\right)$. 


\section{Supplementary material 1}

Factor and item structure of the C-BARQ. Items $37-53$ in the miscellaneous section are the added questions.

\section{1 (Subscale): Trainability (frequency scale)}

Dog returns immediately when called while off leash

Dog obeys a "sit" command immediately

Dog obeys a "stay" command immediately

Dog seems to attend to or listen closely to everything the owner says or does

Dog is slow to respond to correction or punishment

Dog is slow to learn new tricks or tasks

Dog is easily distracted by interesting sights, sounds, or smells

Dog will fetch or attempt to fetch sticks, balls, and other objects

\section{2 (Subscale): Stranger-directed aggression (severity scale)}

Dog acts aggressively

When approached directly by an unfamiliar adult while being walked or exercised on a leash.

When approached directly by an unfamiliar child while being walked or exercised on a leash

Toward unfamiliar persons approaching the dog while it is in the owner's car When an unfamiliar person approaches the owner or a member of the owner's family at home

When an unfamiliar person approaches the owner or a member of the owner's family away from home

When mailmen or other delivery workers approach the home

When strangers walk past the home while the dog is in the yard

When an unfamiliar person tries to touch or pet the dog

When joggers, cyclists, roller skaters, or skateboarders pass the home while the dog is in the yard

Toward unfamiliar persons visiting the home

\section{3 (Subscale): Owner-directed aggression (severity scale)}

Dog acts aggressively

When verbally corrected or punished by a member of the household

When toys, bones, or other objects are taken away by a member of the household

When bathed or groomed by a member of the household

When approached directly by a member of the household while it is eating

When food is taken away by a member of the household

When stared at directly by a member of the household

When stepped over by a member of the household

When a member of the household retrieves food or objects stolen by the dog

4 (Subscale): Dog rivalry (severity scale) 
Dog acts aggressively

Towards another (familiar) dog in your household.

When approached at a favourite resting/sleeping place by another household dog

When approached while eating by another household dog

When approached while playing with/chewing a favourite toy, bone, object by another household dog

5 (Subscale): Stranger-directed fear (severity scale)

Dog acts anxious or fearful

When approached directly by an unfamiliar adult while away from the home When approached directly by an unfamiliar child while away from the home When unfamiliar persons visit the home

When an unfamiliar person tries to touch or pet the dog

6 (Subscale): Non-social fear (severity scale)

Dog acts anxious or fearful

In response to sudden or loud noises

In heavy traffic

In response to strange or unfamiliar objects on or near the sidewalk

During thunderstorms, firework displays, or similar

When first exposed to unfamiliar situations

In response to wind or wind-blown objects

7 (Subscale): Dog-directed aggression (severity scale)

Dog acts aggressively

When approached directly by an unfamiliar male dog while being walked or exercised on a leash

When approached directly by an unfamiliar female dog while being walked or exercised on a leash

Toward unfamiliar dogs visiting the home

When barked, growled or lunged at by an unfamiliar dog

8 (Subscale): Dog-directed fear (severity scale)

Dog acts anxious or fearful

When approached directly by an unfamiliar dog of the same or larger size

When approached directly by an unfamiliar dog of a smaller size

When unfamiliar dogs visit the home.

When barked, growled or lunged at by an unfamiliar dog

9 (Subscale): Touch sensitivity (severity scale)

Dog acts anxious or fearful

When examined or treated by a veterinarian

When having its nails clipped by a household member

When groomed or bathed by a household member

When having feet towelled by a household member

10 (Subscale): Separation-related behaviour (frequency scale)

Shaking, shivering or trembling when left or about to be left on its own

Excessive salivation when left or about to be left on its own

Restlessness/agitation/pacing when left or about to be left on its own 
Whining when left or about to be left on its own

Barking when left or about to be left on its own

Howling when left or about to be left on its own

Chewing or scratching at doors, floor, windows, and curtains when left or about to be left on its own.

Loss of appetite when left or about to be left on its own

11 (Subscale): Excitability (severity scale)

When a member of the household returns home after a brief absence

When playing with a member of the household

When the doorbell rings

Just before being taken for a walk

Just before being taken on a car trip

When visitors arrive at its home

12 (Subscale): Attachment/attention-seeking (frequency scale)

Dog displays a strong attachment for a particular member of the household

Dog tends to follow a member of household from room to room about the house

Dog tends to sit close to or in contact with a member of the household when that individual is sitting down

Dog tends to nudge, nuzzle, or paw a member of the household for attention when that individual is sitting down

Dog becomes agitated when a member of the household shows affection for another person

Dog becomes agitated when a member of the household shows affection for another dog or animal

13 (Subscale): Chasing (frequency scale)

Dog acts aggressively toward cats, squirrels, and other animals entering its yard

Dog chases or would chase cats given the opportunity

Dog chases or would chase birds given the opportunity

Dog chases or would chase squirrels, rabbits and other small animals given the opportunity

14 (Subscale): Energy level (frequency scale)

Dog is playful, puppyish, and boisterous

Dog is active, energetic, and always on the go

Miscellaneous (frequency scales, yes/no and written answers)

15 Escapes or would escape home or yard given a chance

16 Rolls in animal droppings or other 'smelly' substances

17 Eats own or other animals' droppings or faeces

18 Chews inappropriate objects

19 Mounts objects, furniture, or people

20 Begs persistently for food when people are eating

21 Steals food

22 Nervous or frightened on stairs

23 Pulls excessively hard when on the leash

24 Urinates against objects/furnishings in your home

25 Urinates when approached, petted, handled or picked up 
26 Urinates when left alone at night, or during the daytime

27 Defecates when left alone at night, or during the daytime

28 Hyperactive, restless, has trouble settling down

29 Stares intently at nothing visible

30 Snaps at (invisible) flies

31 Chases own tail/hind end

33 Barks persistently when alarmed or excited

34 Licks him/herself excessively

35 Licks people or objects excessively

36 Displays other bizarre, stranger or repetitive behaviour(s)

Added survey items

37 The dog plays when you invite

38 You play when the dog invites

39 The dog gets to play as reward

40 The dog gets food as reward

41 Other dogs in household (number of)

42 Other animals but dog in household (which)

43 Children in household (number and age)

44 Has the dog been moved (when)?

45 Has the dog been in a car accident (when)?

46 Has the dog been in a dog fight (when)?

47 Has the dog been biting (when)?

48 Has the dog been in training (what)?

49 Has the dog shown a tendency to be frightened of shooting sounds?

50 What food has the dog been given (supplements)?

51 Has the dog been to a veterinarian (why)?

52 How many hours a day (on average) is the dog home alone?

53 How many hours a day (on average) is the dog active (e.g. walking, exercising)? 
Supplementary material 2. Operational definitions of behavioural ratings given during each sub-test of the standardised temperament test ( $T$ test). The ratings are set so the most favourable outcome generates the higher values. $T L=$ test leader.

\begin{tabular}{|c|c|c|c|c|c|c|}
\hline Subtest & Rating & 1 & 2 & 3 & 4 & 5 \\
\hline $\begin{array}{l}\text { Affability and } \\
\text { handling }\end{array}$ & Affability & $\begin{array}{l}\text { Rejects contact, } \\
\text { withdraws. }\end{array}$ & $\begin{array}{l}\text { Does not reject contact. } \\
\text { No withdrawal. }\end{array}$ & $\begin{array}{l}\text { Does not reject } \\
\text { contact. No } \\
\text { withdrawal. Makes } \\
\text { contact within } 15 \mathrm{~s} .\end{array}$ & $\begin{array}{l}\text { Makes } \\
\text { spontaneous } \\
\text { contact without } \\
\text { jumping and } \\
\text { vocalization. }\end{array}$ & $\begin{array}{l}\text { Intensive contact } \\
\text { with vocalization or } \\
\text { jumping at person. }\end{array}$ \\
\hline $\begin{array}{l}\text { Affability and } \\
\text { handling }\end{array}$ & Handling & $\begin{array}{l}\text { Rejects, growls, tries to } \\
\text { bite/escape. }\end{array}$ & $\begin{array}{l}\text { Pulls away, seeks } \\
\text { support from handler. }\end{array}$ & Accepts handling. & $\begin{array}{l}\text { Accepts handling, } \\
\text { seeks contact with } \\
\text { TL. }\end{array}$ & $\begin{array}{l}\text { Overwhelming } \\
\text { contact towards TL } \\
\text { when handled. }\end{array}$ \\
\hline Leash & Leash & $\begin{array}{l}\text { Acts on its own. No } \\
\text { contact with handler. }\end{array}$ & $\begin{array}{l}\text { Acts on its own. } \\
\text { Attentive when handle } \\
\text { demanding. }\end{array}$ & $\begin{array}{l}\text { Follows without } \\
\text { handler demanding. }\end{array}$ & $\begin{array}{l}\text { Dependent. } \\
\text { Looking for } \\
\text { confirmation from } \\
\text { handler. }\end{array}$ & \\
\hline Tug-of-war & Tug-of-war & Does not take rag. & $\begin{array}{l}\text { Takes rag. Let go before } \\
\text { handler pulls. }\end{array}$ & $\begin{array}{l}\text { Takes rag. Let go when } \\
\text { handler pulls. }\end{array}$ & $\begin{array}{l}\text { Pulls hard on rag } \\
\text { but let go when } \\
\text { handler pulls back } \\
\text { hard or make loud } \\
\text { noises. }\end{array}$ & $\begin{array}{l}\text { Pulls hard on rag. } \\
\text { Does not let go } \\
\text { despite hard } \\
\text { resistance or } \\
\text { disturbances. }\end{array}$ \\
\hline Retrieving & Chasing & Does not run after ball. & $\begin{array}{l}\text { Starts running but stops } \\
\text { before reaching the ball. }\end{array}$ & $\begin{array}{l}\text { Runs after and takes } \\
\text { the ball. }\end{array}$ & $\begin{array}{l}\text { Runs after and } \\
\text { carries ball back to } \\
\text { handler. }\end{array}$ & $\begin{array}{l}\text { Runs after with high } \\
\text { intensity and carries } \\
\text { ball back to handler. }\end{array}$ \\
\hline Retrieving & $\begin{array}{l}\text { Interest in } \\
\text { object }\end{array}$ & Does not take ball. & $\begin{array}{l}\text { Grabs ball but let go } \\
\text { immediately. }\end{array}$ & $\begin{array}{l}\text { Grabs ball, carries less } \\
\text { than } 5 \mathrm{~s} .\end{array}$ & Grabs ball, carries. & $\begin{array}{l}\text { Grabs ball intensely, } \\
\text { carries }\end{array}$ \\
\hline Dark room & $\begin{array}{l}\text { Reaction in } \\
\text { dark room }\end{array}$ & $\begin{array}{l}\text { Attempts to leave the } \\
\text { room. }\end{array}$ & $\begin{array}{l}\text { Freezes when light are } \\
\text { out. }\end{array}$ & $\begin{array}{l}\text { Walks into the room } \\
\text { less then } 3 \mathrm{~m} \text { and stops. }\end{array}$ & $\begin{array}{l}\text { Investigates but is } \\
\text { affected. Goes to } \\
\text { puppy raiser but } \\
\text { with help. }\end{array}$ & $\begin{array}{l}\text { Investigates without } \\
\text { hesitation or finds } \\
\text { puppy raiser directly. }\end{array}$ \\
\hline Metal stair & Metal stair & $\begin{array}{l}\text { Refuses to follow puppy } \\
\text { raiser. }\end{array}$ & $\begin{array}{l}\text { Starts to follow but then } \\
\text { refuses after some } \\
\text { steps. }\end{array}$ & $\begin{array}{l}\text { Manages to walk the } \\
\text { whole stairway but } \\
\text { with major hesitation. }\end{array}$ & $\begin{array}{l}\text { Easily walks the } \\
\text { stairway, but with } \\
\text { slight hesitation. }\end{array}$ & $\begin{array}{l}\text { Walks the stairway } \\
\text { without hesitation. }\end{array}$ \\
\hline Unstable table & $\begin{array}{l}\text { Reaction on } \\
\text { unstable table }\end{array}$ & $\begin{array}{l}\text { Tries to escape before } \\
\text { table is moving. }\end{array}$ & $\begin{array}{l}\text { Tries to escape when } \\
\text { table is moving. }\end{array}$ & $\begin{array}{l}\text { Visibly uncomfortable } \\
\text { with a low tense body- } \\
\text { posture but does not }\end{array}$ & $\begin{array}{l}\text { Tense but not } \\
\text { annoyed. }\end{array}$ & $\begin{array}{l}\text { Unaffected. Dog is } \\
\text { just standing still } \\
\text { while table is }\end{array}$ \\
\hline
\end{tabular}




\begin{tabular}{|c|c|c|c|c|c|c|}
\hline & & & & try to escape. & & moving. \\
\hline Subtest & Rating & 1 & 2 & 3 & 4 & 5 \\
\hline Unstable table & Object & Does not take ball. & $\begin{array}{l}\text { Takes ball but let go } \\
\text { when table moves. }\end{array}$ & $\begin{array}{l}\text { Holds ball despite } \\
\text { moving table. }\end{array}$ & & \\
\hline Acoustic Startle & Flight distance & Escapes $*>5 \mathrm{~m}$. & Escapes 2-5 m. & Escapes 1-2 m. & $\begin{array}{l}\text { Takes one or two } \\
\text { steps backwards } \\
\text { without escaping. }\end{array}$ & No fear response. \\
\hline Acoustic Startle & $\begin{array}{l}\text { Secondary } \\
\text { response }\end{array}$ & $\begin{array}{l}\text { Does not want to } \\
\text { investigate buckets } \\
\text { despite encouragement. }\end{array}$ & $\begin{array}{l}\text { Investigates buckets } \\
\text { but only with major } \\
\text { encouragement. }\end{array}$ & $\begin{array}{l}\text { Investigates buckets } \\
\text { with some help from } \\
\text { handler. }\end{array}$ & $\begin{array}{l}\text { Investigates } \\
\text { buckets without } \\
\text { help but with } \\
\text { hesitation. }\end{array}$ & $\begin{array}{l}\text { Investigates buckets } \\
\text { without hesitation. }\end{array}$ \\
\hline Acoustic Startle & Lasting effect & $\begin{array}{l}\text { Very affected. } \\
\text { Persistent avoidance. }\end{array}$ & $\begin{array}{l}\text { Affected. Is passing but } \\
\text { active avoidance. }\end{array}$ & $\begin{array}{l}\text { A bit affected. Change } \\
\text { in body-posture when } \\
\text { passing. }\end{array}$ & $\begin{array}{l}\text { Unaffected but is } \\
\text { looking at object. }\end{array}$ & No lasting effect. \\
\hline Visual Startle & Flight distance & Escapes* $>5$ m. & Escapes 2-5 m. & Escapes 1-2 m. & $\begin{array}{l}\text { Jerks without } \\
\text { escaping. }\end{array}$ & No fear response. \\
\hline Visual Startle & Aggression & $\begin{array}{l}\text { No sign of aggression. } \\
\text { I.e. pilo-erection, } \\
\text { barking or growling. }\end{array}$ & $\begin{array}{l}\text { Some sign of } \\
\text { aggression. Barking or } \\
\text { pilo-erection. }\end{array}$ & $\begin{array}{l}\text { Clear signs of } \\
\text { aggression, pilo- } \\
\text { erection or growling. }\end{array}$ & $\begin{array}{l}\text { Strong aggression, } \\
\text { including mouth } \\
\text { threat. }\end{array}$ & $\begin{array}{l}\text { Attacks and bites the } \\
\text { coverall. }\end{array}$ \\
\hline Visual Startle & $\begin{array}{l}\text { Secondary } \\
\text { response }\end{array}$ & $\begin{array}{l}\text { Does not investigate } \\
\text { coveralls }\end{array}$ & $\begin{array}{l}\text { Investigates coveralls } \\
\text { with major } \\
\text { encouragement. }\end{array}$ & $\begin{array}{l}\text { Investigates coveralls } \\
\text { with some } \\
\text { encouragement. }\end{array}$ & $\begin{array}{l}\text { Investigates } \\
\text { coveralls without } \\
\text { help but with } \\
\text { hesitation. }\end{array}$ & $\begin{array}{l}\text { Investigates } \\
\text { coveralls without } \\
\text { hesitation. }\end{array}$ \\
\hline Visual Startle & Lasting effect & $\begin{array}{l}\text { Very affected. } \\
\text { Persistent avoidance of } \\
\text { coverall. }\end{array}$ & $\begin{array}{l}\text { Affected. Passes but } \\
\text { shows active avoidance } \\
\text { of coverall. }\end{array}$ & $\begin{array}{l}\text { Mildly affected. Change } \\
\text { in body posture when } \\
\text { passing. }\end{array}$ & $\begin{array}{l}\text { Unaffected but is } \\
\text { looking at object } \\
\text { when passing. }\end{array}$ & No lasting effect. \\
\hline $\begin{array}{l}\text { Gradual Visual } \\
\text { Startle }\end{array}$ & Fearfulness & $\begin{array}{l}\text { Freezes or tries to } \\
\text { escape. }\end{array}$ & No reaction. & $\begin{array}{l}\text { Switches between } \\
\text { fight/flight responses. }\end{array}$ & $\begin{array}{l}\text { Strong fight } \\
\text { reaction towards } \\
\text { figure, but without } \\
\text { attack. }\end{array}$ & $\begin{array}{l}\text { Attacks and bites } \\
\text { figure. }\end{array}$ \\
\hline
\end{tabular}




\begin{tabular}{|c|c|c|c|c|c|c|}
\hline Subtest & Rating & 1 & 2 & 3 & 4 & 5 \\
\hline $\begin{array}{l}\text { Gradual Visual } \\
\text { Startle }\end{array}$ & Aggression & $\begin{array}{l}\text { No sign of aggression. } \\
\text { I.e. pilo-erection, } \\
\text { barking, growling. }\end{array}$ & $\begin{array}{l}\text { Some sign of } \\
\text { aggression. Barking or } \\
\text { Pilo-erection. }\end{array}$ & $\begin{array}{l}\text { Clear sign of } \\
\text { aggression, pilo- } \\
\text { erection. }\end{array}$ & $\begin{array}{l}\text { Strong aggression, } \\
\text { growls, mouth } \\
\text { threat. }\end{array}$ & Bites. \\
\hline $\begin{array}{l}\text { Gradual Visual } \\
\text { Startle }\end{array}$ & $\begin{array}{l}\text { Secondary } \\
\text { response }\end{array}$ & $\begin{array}{l}\text { Does not investigate } \\
\text { figure. }\end{array}$ & $\begin{array}{l}\text { Investigates figure with } \\
\text { major encouragement. }\end{array}$ & $\begin{array}{l}\text { Investigates figure } \\
\text { with some } \\
\text { encouragement. }\end{array}$ & $\begin{array}{l}\text { Investigates figure } \\
\text { without help but } \\
\text { with hesitation. }\end{array}$ & $\begin{array}{l}\text { Investigates figure } \\
\text { without hesitation. }\end{array}$ \\
\hline $\begin{array}{l}\text { Gradual Visual } \\
\text { Startle }\end{array}$ & Lasting effect & $\begin{array}{l}\text { Very affected. } \\
\text { Persistent avoidance of } \\
\text { figure. }\end{array}$ & $\begin{array}{l}\text { Affected. Passes but } \\
\text { shows active avoidance } \\
\text { of figure. }\end{array}$ & $\begin{array}{l}\text { Mildly affected. Change } \\
\text { in body-posture when } \\
\text { passing. }\end{array}$ & $\begin{array}{l}\text { Unaffected but is } \\
\text { looking at object } \\
\text { when passing. }\end{array}$ & No lasting effect. \\
\hline Search & Intensity & Does not search. & Searches but stops. & $\begin{array}{l}\text { Searches from } \\
\text { different directions. }\end{array}$ & $\begin{array}{l}\text { Searches } \\
\text { intensively, uses } \\
\text { mouth or paws. }\end{array}$ & $\begin{array}{l}\text { Searches intensively, } \\
\text { uses mouth and } \\
\text { paws. }\end{array}$ \\
\hline Search & Persistence & Does not start search. & Searches $<10$ s. & Searches $<1 \mathrm{~min}$. & Searches $<2 \mathrm{~min}$. & Searches $>2 \mathrm{~min}$. \\
\hline Gunfire & Fearfulness & $\begin{array}{l}\text { Very fearful, tries to } \\
\text { escape in leash. }\end{array}$ & $\begin{array}{l}\text { Stops playing, not } \\
\text { playful afterwards. }\end{array}$ & $\begin{array}{l}\text { Stops playing, cannot } \\
\text { be encountered in play } \\
\text { afterwards. }\end{array}$ & No reaction. & \\
\hline Gunfire & Curiosity & No reaction. & $\begin{array}{l}\text { Stops playing, looks in } \\
\text { direction of gunfire. }\end{array}$ & $\begin{array}{l}\text { Stops playing, pulling } \\
\text { on leash in direction of } \\
\text { gunfire. }\end{array}$ & $\begin{array}{l}\text { Stops playing, want } \\
\text { to investigate, } \\
\text { whines, whimpers. }\end{array}$ & $\begin{array}{l}\text { Very excited, pulling } \\
\text { on leash in direction } \\
\text { of gunfire cannot be } \\
\text { calmed. }\end{array}$ \\
\hline
\end{tabular}


Supplementary material 3. Comparison of the principal component analysis between current study (left column) and Wilsson and Sinn (2012) (right column). The table shows the Temperament test (T-test) variable loadings on the six components with eigenvalues $>1$. The combined values of Environmental Sureness and Acoustic Environmental Sureness in the current study seem to jointly correspond to

Environmental Sureness in Wilsson and Sinn (2012). Loadings over 0.5 are shown in bold. A= Acoustic Startle sub-test; G= Gradual

Visual Startle sub-test; V= Visual Startle sub-test.

\begin{tabular}{|c|c|c|c|c|c|c|c|c|c|c|c|}
\hline \multirow[b]{2}{*}{ Affability } & \multicolumn{2}{|c|}{ Confidence } & \multicolumn{2}{|c|}{$\begin{array}{c}\text { Physical } \\
\text { Engagement }\end{array}$} & \multicolumn{2}{|c|}{$\begin{array}{c}\text { Social } \\
\text { Engagement }\end{array}$} & \multicolumn{2}{|c|}{$\begin{array}{l}\text { Environmental } \\
\text { Sureness }\end{array}$} & \multirow{2}{*}{$\begin{array}{c}\begin{array}{c}\text { Acoustic } \\
\text { Environ. } \\
\text { Sureness }\end{array} \\
-0.08\end{array}$} & \multicolumn{2}{|c|}{ Aggression } \\
\hline & 0.03 & 0.14 & 0.29 & -0.04 & 0.68 & -0.76 & 0.00 & -0.16 & & -0.02 & -0.16 \\
\hline Handling & -0.01 & 0.12 & -0.17 & 0.14 & 0.86 & -0.80 & -0.03 & 0.01 & 0.02 & -0.13 & -0.08 \\
\hline Leash & 0.12 & 0.07 & 0.25 & 0.37 & 0.81 & -0.64 & 0.14 & 0.03 & -0.08 & -0.01 & 0.00 \\
\hline Tug-of-war & -0.08 & -0.07 & 0.69 & 0.70 & 0.26 & -0.25 & 0.10 & -0.02 & 0.20 & 0.13 & 0.09 \\
\hline Chasing & -0.05 & -0.13 & 0.81 & 0.78 & 0.13 & -0.20 & 0.20 & -0.11 & 0.03 & 0.09 & 0.01 \\
\hline Interest in object & 0.04 & -0.08 & 0.76 & 0.74 & -0.02 & -0.20 & 0.18 & -0.10 & 0.05 & 0.21 & -0.03 \\
\hline Reaction in dark room & 0.33 & 0.21 & 0.23 & 0.02 & -0.15 & -0.07 & 0.77 & -0.56 & 0.04 & -0.15 & 0.05 \\
\hline Metal stair & 0.07 & 0.09 & 0.26 & 0.12 & 0.27 & -0.04 & 0.72 & -0.62 & 0.07 & 0.19 & -0.09 \\
\hline Reaction on table & -0.11 & 0.04 & 0.38 & 0.14 & 0.05 & -0.02 & 0.73 & -0.71 & 0.22 & 0.14 & -0.05 \\
\hline Object & -0.07 & -0.02 & 0.74 & 0.66 & 0.15 & 0.11 & 0.29 & -0.31 & 0.06 & -0.12 & -0.12 \\
\hline A. Flight distance & 0.19 & 0.38 & 0.19 & 0.06 & -0.08 & 0.03 & -0.10 & -0.45 & 0.80 & 0.11 & 0.13 \\
\hline $\begin{array}{l}\text { A. Secondary } \\
\text { response }\end{array}$ & 0.17 & -0.12 & 0.00 & -0.03 & -0.11 & 0.01 & 0.29 & -0.46 & 0.70 & -0.01 & 0.06 \\
\hline A. Lasting effect & 0.29 & 0.52 & 0.12 & -0.05 & 0.04 & -0.03 & 0.12 & -0.41 & 0.71 & 0.19 & 0.11 \\
\hline V. Flight distance & 0.65 & 0.79 & 0.23 & -0.14 & 0.13 & -0.06 & -0.29 & -0.07 & 0.32 & 0.20 & -0.02 \\
\hline V. Aggression & -0.01 & -0.11 & -0.03 & 0.04 & -0.07 & 0.08 & 0.04 & -0.08 & 0.10 & 0.80 & 0.86 \\
\hline $\begin{array}{l}\text { V. Secondary } \\
\text { response }\end{array}$ & 0.80 & 0.81 & 0.02 & 0.03 & 0.06 & -0.16 & 0.08 & 0.12 & 0.15 & -0.14 & -0.08 \\
\hline V. Lasting effect & 0.86 & 0.87 & 0.05 & -0.06 & 0.05 & -0.04 & -0.02 & -0.05 & 0.11 & 0.00 & -0.06 \\
\hline G. Fearfulness & 0.65 & 0.63 & 0.08 & 0.10 & -0.18 & -0.04 & -0.02 & 0.01 & 0.05 & 0.55 & 0.37 \\
\hline G. Aggression & 0.40 & 0.25 & 0.06 & 0.06 & -0.04 & 0.07 & 0.10 & -0.05 & 0.15 & 0.71 & 0.74 \\
\hline $\begin{array}{l}\text { G. Secondary } \\
\text { response }\end{array}$ & 0.84 & 0.71 & 0.01 & 0.18 & -0.04 & -0.02 & 0.16 & 0.09 & 0.11 & 0.19 & -0.01 \\
\hline G. Lasting effect & 0.75 & 0.78 & 0.05 & 0.10 & 0.11 & 0.05 & 0.20 & -0.06 & 0.20 & 0.20 & 0.00 \\
\hline
\end{tabular}




\begin{tabular}{|c|c|c|c|c|c|c|c|c|c|c|c|}
\hline \multirow[b]{2}{*}{ Search Intensity } & \multicolumn{2}{|c|}{ Confidence } & \multicolumn{2}{|c|}{$\begin{array}{c}\text { Physical } \\
\text { Engagement }\end{array}$} & \multicolumn{2}{|c|}{$\begin{array}{c}\text { Social } \\
\text { Engagement }\end{array}$} & \multicolumn{2}{|c|}{$\begin{array}{l}\text { Environmental } \\
\text { Sureness }\end{array}$} & \multirow{2}{*}{$\begin{array}{c}\begin{array}{c}\text { Acoustic } \\
\text { Environ. } \\
\text { Sureness }\end{array} \\
0.08\end{array}$} & \multicolumn{2}{|c|}{ Aggression } \\
\hline & 0.24 & 0.23 & 0.83 & 0.82 & -0.01 & 0.15 & 0.03 & 0.10 & & -0.12 & 0.06 \\
\hline Search Persistence & 0.33 & 0.27 & 0.76 & 0.79 & 0.00 & 0.18 & 0.04 & 0.08 & 0.03 & -0.11 & 0.06 \\
\hline Gunfire. Fear & & 0.41 & & 0.10 & & 0.04 & & -0.11 & & & 0.10 \\
\hline Curiosity & & -0.06 & & -0.07 & & -0.37 & & 0.06 & & & 0.30 \\
\hline$\%$ variance explained & 17.9 & 31.2 & 17.8 & 10.4 & 9.3 & 7.2 & 9.2 & 5.4 & 8.6 & 8.0 & 5.7 \\
\hline
\end{tabular}

